\title{
The Meroitic Empire: Trade and Cultural Influences in an Indian Ocean Context
}

\section{Randi Haaland}

Published online: 21 November 2014

(C) The Author(s) 2014. This article is published with open access at Springerlink.com

\begin{abstract}
The Meroitic Empire was a powerful Kushite state in the Middle Nile region of the Sudan, lasting from the fourth century BCE to the fourth century CE. In the early phase from the ninth century BCE, the seat of power was in the north at Napata. Influences from Egypt clearly dominated symbolic expressions of royal power in this early phase, but over time, elements linked to different cultural traditions occurred. Here, I explore the possibility that some of these new elements (e.g. the lion god Apedemak and elephant imagery) may be related to interactions across the Indian Ocean involving trade, migrations of craft specialists and the diffusion of ideas.
\end{abstract}

Résumé L'empire de meroe était une puissance Kushite dans la région du Moyen-Nil du Soudan, à partir du 4ème siècle avant notre ère jusqu'au 4ème siècle. Les influences de l'Egypte dominent les expressions symboliques du pouvoir royal dans la première phase, mais au fil du temps, des éléments liés à des traditions culturelles différentes se produisent. Je vais étudier la possibilité que certains de ces nouveaux éléments (par exemple, le lion dieu Apédémak, et l'imagerie de l'éléphant) peuvent être liées à des interactions à travers de l'océan Indien; des interactions commerciales, de migrations de artisans, et de la diffusion des idées.

Keywords Meroe - Indian Ocean · Trade · Craft - Symbolic influence .

Apedemak lion god $\cdot$ Elephants

It is probable that, when the influence of India on Meroe at this period is realized, other traces will be recognized. (Arkell 1951, p. 36)

...the ways between Rome, Persia, India, and China were opened in this period to an ever increasing commerce, and to such a degree that nowhere in the hemisphere was there any longer the possibility of local mythological developments in isolation.

R. Haaland $(\square)$

University of Bergen, Bergen, Norway

e-mail: randi.haland@ahkr.uib.no 
The exchange of ideas was multifarious. And yet, there was in each domain a local force (I have termed style or signature). (Campell 1979, p. 288)

\section{Introduction}

Texts pertaining to early global history tend to focus on Eurasian, Indian, Chinese and Southeast Asian trade connections; African connections are given less consideration, although Edens and Kohl (1993) refer to Sudan and the Arabian Peninsula as being included in West Asian Bronze Age trade. During Pharaonic times, Sudan's position in global trade was largely related to the flow of goods such as ivory and gold, as well as slaves that were channelled to Egypt. This position changed as politico-economic processes affected movements of goods over regions of global scale from the Roman Hellenistic world to South Asia. This became particularly important in the area and time I shall discuss here, namely, the Kushite kingdom of Meroe, which represents a later development of the Kushite kingdom of Napata.

The Lower Nile area up to the Mediterranean had, since the fourth millennium BCE, been dominated by the Egyptian kingdoms that for 3,000 years exerted immense power in the Mediterranean world and the African regions to the south. The stability of Egyptian dynasties was supported not only by military/administrative power and economic productivity, but also by the development of a rich universe of legitimating religious beliefs and symbolic constructions of monumental scale. This had an enormous impact on the developments that took place in the Meroitic kingdoms. There are therefore good reasons why archaeologists who have researched Merotic civilization have been oriented towards explaining its cultural remains by searching for connections to Egyptian civilization.

My agenda here is not to deny the impact of Egypt on Meroe, but rather to ask questions about elements in the inventory of Meroitic archaeological material that indicate influences from other cultural traditions. Local non-Egyptian African traditions are obviously important, but I shall here focus on another direction, namely, the possible South Asian connection.

\section{Who Were the People of Kush?}

The people of the Kushite states were close neighbours of the Egyptian empire, but just how culturally similar were the two peoples? The clearest cultural feature marking the people of Meroe as distinct from the ancient Egyptians is the language spoken in a succession of so-called Kushite kingdoms, a language that developed into written form in the last stage of the civilization of Kush in the fourth century BCE. According to Rilly (2004), a list of proto-Meroitic names of individuals, obviously important figures of the first dynastic Kushite state, the Kingdom of Kerma appears in an Egyptian papyrus from the second millennium BCE (Rilly and de Voogt 2012, p. 5). As early as 1969, Trigger suggested that the written Meroitic language belonged to the Nilotic branch of the NiloSaharan language family, instead of the Afro-Asiatic language family to which the Egyptian language family belonged. Although this hypothesis was generally rejected at the time, Rilly $(2004,2007,2009)$ has now argued convincingly that this is the most 
plausible connection, and this also makes sense in terms of the present distribution of Nilotic languages. It is thus highly likely that people speaking varieties of Nilo-Saharan languages occupied the Middle Nile region as well as people speaking other languages such as Kushitic (Haaland and Haaland 2007; Haaland 2013).

Ethnographic observations have shown a clear cultural difference between the Nubian-speaking cultivators along the Nile (the more recent Arabic-speaking nomads and cultivators are left out of the discussion here) and the Cushitic-speaking (of the Afro-Asiatic language family) nomads who have adapted to the dry savannah region between the Nile and the Red Sea. It is assumed that the nomads are related culturehistorically to the so-called Blemmyes mentioned in ancient Egyptian texts (Arkell 1961; Sadr 1990; Haaland 1992). While the language is quite different from Egyptian, other cultural features manifested in the material recovered from archaeological sites in the Meroitic area clearly show similarity, especially within the ruling elite.

\section{A Historical Outline}

As already mentioned, there is written evidence for a Kushite kingdom at Kerma, and archaeological evidence indicates that this kingdom may date back to $2400 \mathrm{BCE}$ or even earlier (Bonnet 2004). Around 1400 BCE, Kerma was conquered by Egyptian forces, after which archaeological material gives few clues about how the Meroitic population of the region was ruled, until the emergence of a new centralized state at Napata in the fourth cataract area during the ninth century BCE. Egyptian written sources as well as inscribed statues show that the twenty-fifth dynasty in Egypt during the eighth century BCE was ruled by Kushite kings from Napata (see map, Fig. 1).

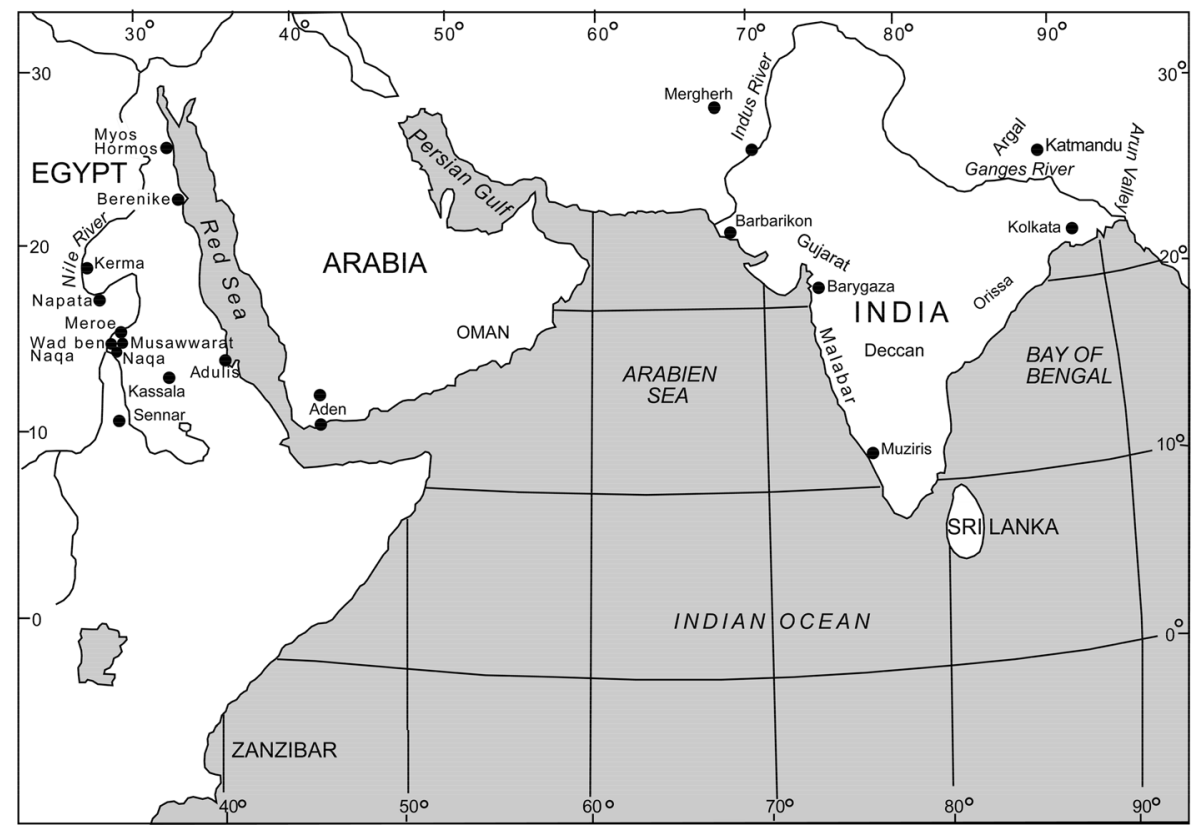

Fig. 1 Map of main localities discussed 
During the fourth century BCE, the Kushite centre was moved from Napata southward to Meroe near the fifth cataract, which remained an important royal city until the fourth century CE (Shinnie 1967; Adams 1977; Welsby 1996; Edwards 2004). When the capital was moved south to Meroe, Egyptian stylistic influences were still dominant in the archaeological inventory, but soon, new influences indicating connections to other civilization centres appeared: first linked to Hellenistic and Roman traditions, but later elements from other sources as well. As Arkell (1951) and others (Shinnie 1967; Hofmann 1975) have pointed out, some of these elements may be better understood if seen in the context of Indian Ocean influences instead of the conventional Egyptian and Mediterranean ones. It is the possibility of such connections between the Kushite state of Meroe and India that I address here. However, before taking up the interpretation of material that is indicative of such connections, I will place Meroe in the wider global contexts of trade and politics at the time.

\section{A Global Perspective on the Rise of Meroe}

In discussing trade in early empires, we should place acquisition of goods at a distance as Polanyi argued back in the 1950s (Polanyi 1957, p. 258).

The specificity of trade is enhanced in the natural course of things by the necessity of acquiring the imported goods with exported ones. For under nonmarket conditions imports and exports tend to fall under different regimes. The process through which goods are collected is mostly separate from, and relatively independent of, that by which the imported goods are repartitioned. (Polanyi 1957, p. 261)

Trade and politics were intimately intertwined in early states. Imported items were dominated by elite interests, and through the states' institutions of redistribution, a mechanism for tying clients to the political centre was established. The centre's need for the collection of goods for export was primarily based on the ability of its military/ administrative apparatus to extract goods through tribute, taxation and raiding. Polanyi has argued that those who were engaged in trade were of two kinds: the ruling elite who depended on control over export and import, and those who carried out the hard work of transporting goods over large distances.

Trade in early states was thus largely a matter of intergovernmental relations and not so much commercial entrepreneurship. An important point is that in this kind of administrative system, trade is not only a matter of the flows of goods and political influence, but also involves the diffusion of ideas and knowledge brought about by migration of occupational specialists whose skills are in demand in faraway communities (Helms 1993; Killick 2009). Events in some parts of the ancient world system thus had repercussions in other parts, restructuring local production and international distribution as well as affecting the growth and decline of states in widely separated regions.

The Kushite state of Meroe rose in a situation of turmoil in the world systems of Eurasia and North Africa. After the decline of the great empires in about 1000 BCE, fundamental cultural developments (the so-called axial breakthroughs) occurred within smaller rival states in various regions, frequently those on the fringes of the great empires: Greece in Europe, Jewish kingdoms in the Middle East, and various 
chiefdoms in South Asia and China (Jaspers 1957; Eisenstadt 2009; Bellah 2011). A characteristic feature of these breakthroughs is the tension between political power and intellectual innovators (Confucius, Buddha, Israel's prophets, Greek philosophers and authors, etc.). Different written languages were standardized, and competing ideas about the position of humans in the cosmic and social order were formulated. In this period of political reorganization and contesting ideological thoughts, important crosscivilizational contacts were maintained through trade, migration and the diffusion of ideas and symbols. The rise and growth of the Meroitic kingdom were heavily influenced by events taking place in global politics at the time and held a strategic position in relation to Indian Ocean trading. There has been a reluctance of many Nubiologists to consider the possibility that Meroe did not act independently outside Africa but required Egypt to serve as intermediary for those relations. Peake (2010) has called this an Egyptocentric attitude. Meroitic Kush interacted directly with international rulers. There are records of Meroitic embassies sent to Rome (Shinnie 1967, p. 23), as well as Constantinople (Peake 2010). Likewise, there is some evidence of the presence of Roman embassies in the vicinity of Meroe (Burstein quoted in Pope 2008, p. 9).

\section{Indian Ocean Trade}

We know from written sources that the Ptolemies and later the Romans sent trading expeditions from Egyptian ports such as Myos Hormos and Berenike in the north, which stopped at Red Sea ports like Adulis in the south, where they collected objects of trade from the African interior. From the second to first centuries BCE, the number of ships that sailed to India increased to more than a hundred annually. Berenike as well as Adulis thus became meeting points between India and Egypt. The Meroitic state was involved in furnishing goods for this trade, probably brought from the African savannah in the west as well as Southern Sudan. The goods included ivory, ebony, rhinoceros horn, leopard and other skins, ostrich feathers, gold and slaves (Arkell 1961; Phillips 1997; see also Thapar 1966, p. 114, for the importance of ivory and gold). The port of Adulis was a central outlet for ivory from the African hinterland; the Periplus (see below) has a brief description of Adulis. Interestingly, Kirwan (1972, p. 166 quoted in Munro-Hay 1982) suggests that ivory from beyond the Nile was brought through Kueneion - possibly modern Sennar, located along the Blue Nile- to Axum. The ivory at Adulis was also brought via Axum, according to the Periplus (pp. 107-108) (see Phillips 1997, p. 450 for further reference).

Most of our information on this early trading network comes from a single source, the Periplus Maris Erythraei (the southern Red Sea, together with the Indian Ocean, was known as the Erythraean Sea). This is a handbook written in Greek by an anonymous author, most likely a sea captain, who comments on the winds, port locations, political situation, peoples and goods along the way, as well as favoured harbours on the Red Sea, African and Indian coasts of the Indian Ocean (Sidebotham 2011, p. 14). Prahba Ray (2003, p. 170), in discussing the significance of written texts such as the Periplus, finds that the correct spelling of names from the Indian subcontinent shows that the writer had travelled the area quite regularly.

Other early Roman writers provide important but more limited information on Indian Ocean trade. These are known historical persons rather than anonymous sources. 
One of the most important is Pliny the Elder (23-79). He wrote several books, the only surviving text of which is the Natural History (NH), a 37-book Latin encyclopaedia. It is book 6, 101-106 that is important in describing the lands involved in Indian Ocean trade, and books 12-13 that describe the natural products of the region. Many of the writers from this period based their texts on secondary sources. Strabo, an Armenian who lived in Alexandria (64 BCE-CE 23), wrote the 37-book Geography in Greek; he travelled to Yemen and Ethiopia, but many of his accounts are based on earlier writers (Tomber 2008, p. 22). The later writer Pomponius Mela wrote De Chorographica, while the Greek writer Cosmas Indicopleustes wrote his book on Christian topography later in the fifth century CE. Seneca has given an account of an expedition ordered by Nero to send two centurions to southern Sudan. They seem to have reached as far as the Sudd, probably to investigate the possibility for trade rather than a military expedition (Nat. quest. VI 8.3). Strabo records (Geography 2.512) that in his day, 20 ships per annum were involved in the trade. The peak of the trade based on the material from Myos Hormos and Berenike seems to have been 120 per annum during the ClaudianNeronian-Flavian period (CE 41-96); see Sidebotham (2011) for further references.

The late Ptolemaic and early Roman expansion of Indian Ocean trade rapidly increased the importance of ports along the Red Sea, where African goods could be acquired for shipments. Myos Hormos was mainly occupied during the first century CE to early third century CE (Tomber 2008, pp. 58-59). Berenike had a longer period of settlement, from the mid-third century BCE with a peak commercial period during the first century CE. The second century, probably due to plague, seems to have been devastating to the port's inhabitants, but Berenike picked up again and was active in trade to the early sixth century CE (Sidebotham 2011, p. 221).

Expeditions across the waters of the Red Sea itself are constrained by the strong northerly winds that blow much of the year, making sailing against them difficult, especially in the northern half. This helps to explain the success of Berenike over Egypt's other more northerly ports, such as Myos Hormos located $300 \mathrm{~km}$ further north. Whitewright (2007) has suggested that the reason for this location becoming important is that the sailors wanted to stop at Berenike to shorten the sailing distance and to avoid the dangerous northerly winds. Adulis, the southernmost of the ports along the Red Sea, would also clearly have benefitted from a similar location.

Direct sea contact between India and the Mediterranean became more common, as a result of the increasing use of the southeast monsoon by seafaring trade based in Roman Egypt. The explosion in Roman demand for South Indian products, including textiles, pearls and especially pepper which rapidly became a staple of Mediterranean cuisine, increased the scale and value of the trade (Sidebotham 2011, pp. 224-225).

The initiative in establishing direct contact between the Mediterranean and India appears to have come from the Indian side in the late second century BCE (Thapar 2000, p. 456). The Ptolemaic rulers of Egypt responded in kind. They dispatched at least two official trading missions to India while establishing a Greek presence on the island of Socotra, just outside the southern entrance to the Red Sea, alongside the already existing Indian and Arabian settlements on the island, and charged a special official with general oversight over commerce in the Red Sea and Indian Ocean. That Indians were exploring westward toward the Red Sea is clear from Strabo's Geography (2.3.4: 98) account of the background to the first Ptolemaic voyages to India. Early trade during the Ptolemaic period of Indian contacts may have been just as much a 
matter of diplomacy as of commerce, involving exchanges of gifts between rulers (Ray 2003, p. 37).

\section{The Meroitic Kingdom and its Position on Trade Routes}

Trigger has argued that trade was of vital importance to the Kushite state, as was the case in the development of early states across Sudanic Africa (Trigger 1985). During different periods, the centre of political control was located in the urban capitals of Napata and Meroe. The distribution of imports suggests that most foreign artefacts entering the Meroitic culture were distributed through an elite network, probably a royal monopoly. During the previous Napatan period, this seems to have taken the form of "Embassy Trade," a form of elite gift exchange widely encountered in the Mediterranean and Near Eastern world (Edwards 1999a). This form of exchange seems to have continued during the Meroitic period, linking the Meroitic kings with successive Ptolemaic and Roman rulers. In such redistributive systems, kings acted as the pivots mediating the flow of goods and services internally between different occupational specialists including cultivators, as well as externally between different kingdoms. The distribution of trade goods shows that Meroe participated in a network of material exchanges, connecting it with the Mediterranean world as well as with the Horn of Africa (Arkell 1951, 1961, 1966; Shinnie 1967; Adams 1977; Welsby 1996; Phillips 1997; Edwards 2004). As will be discussed below, I will argue for the importance of mainly "invisible" trade goods such as spices and textiles that were probably part of this trade across the Red Sea to India. These trade commodities have been recovered in large quantities at the Red Sea site of Berenike.

The Meroitic state located in southern Butana held a strategic position for control of the overland trade route that connected the Nile and the Red Sea, and regions further west across the African savannah (Edwards 1999a). The capital Meroe was obviously one of them; another city was Wad ben Naqa located just south of Meroe, along the Nile. Wad ben Naqa appears to have been a city of considerable size, with remains of temples and a palace, in which there were vaulted storerooms where stockpiles of ivory have been recovered (Shinnie 1967, p. 87). Other Meroitic sites were well known for their stockpiles of ebony and ivory (Welsby 1996, p. 175). Further east, the city of Naqa was located on the trade route connecting the Nile with the Red Sea as well as Musawwarat es Sufra, important as both a ritual and trade centre (Shinnie 1967, p. 87). Shinnie argued that these sites were situated along wadis with a distance of about a one-day camel or donkey journey from the river Nile. The importance of these sites was their location along wadis, which also had good agricultural potential.

Our knowledge of the two major trading corridors, the Red Sea and the Nile, is well attested. However, the overland trade networks are not well documented. As emphasized by Phillips (1997), different tribal groups might have exerted some control of the overland trade routes, but it is likely that the Meroitic State had an interest in constraining their power. As suggested earlier, Cushitic-speaking pastoralists probably inhabited this area. An indication of the importance of centralized control over trade between the two corridors is found at the site of el Qeili, located on the road between Khartoum and Kassala. Incised on a large boulder, we see King Shorkaror, in full royal regalia, holding in one hand weapons, spears and a bow and arrow, while in the other, a 
long cord with several bound captives. Torok (1997, p. 466) interprets this as an indication of war and conflict and an attempt to pacify the region in a period when maintenance of undisturbed trade contacts within the region was vital (Shinnie 1967, p. 50). Shorkaror ruled during the first century $\mathrm{CE}$ at a time when this trade was at its peak, and access to luxury trade goods from the interior of Africa was vital. Recently, some material has been recovered that appears to show contact between the Nile and Red Sea corridors, pottery of so-called Eastern Desert ware. The pottery recovered here is similar to sherds found at the Gabati site located along the Nile just north of Meroe and Berenike (Magid 1998; Barnard and Magid 2004; Manzo 2004). Magid discusses an important site, Tabot, which he interprets as a way-station for trading in the southern Red Sea Hills (Magid 1998). Recently, a statue discovered at Dangeil dated to the 25th dynasty contains a reference to the toponym MS(T) that Zyhlarz has tentatively identified as a port on the Red Sea coast (Anderson and Ahmed 2009). This might give us an indication of possible connection between the Nile corridor and the Red Sea.

The Ptolemies and later the Romans sent trading expeditions from Egyptian ports in the North, stopping at the Red Sea port of Adulis where they collected objects of trade from the African interior. It appears that Axum was an important collecting point for African ivory, from where it was exported to Adulis and traded to the Roman Empire (Adams 1977, p. 385; Munro-Hay 1982; Welsby 1996, p. 176; Edwards 2004, p. 184). The Periplus describes the port of Adulis and states that 8-day's journey inland lay the metropolis of the Axumites where the ivory from beyond the Nile was carried, and from where it was exported to Adulis and traded to the Roman Empire (cited in Adams 1977, p. 385; see also Casson 1989, pp. 107-108; Tomber 2008, p. 89). As referred to earlier, according to Seneca in the first century CE, even Emperor Nero sent an expedition to an area that was probably located in the Sudd region of Southern Sudan, to explore the possibility of exploiting the resources of this remote area (Seneca NH 6.8.3-4).

\section{Elite Consumption}

The Kushites had a long history of trade with Egypt that was primarily associated with small quantities of non-utilitarian luxury products distributed as gifts between elites and state-controlled embassies (Edwards 1999a). Egyptian imports included luxury goods, especially vessels for serving and display (Torok 1989; Edwards 2004, p. 167-168). The Ptolemaic and Roman trade goods were vessels used for conspicuous consumption among the Kushite elite. Elements of their cuisine, such as wine and bread, were influenced by the Mediterranean tradition. Pepper was a status symbol of fine cookery in the Roman Empire and descriptions of lavish feasts invariably mention pepper. Although many spices entered Roman cuisine, an emphasis on pepper is particularly visible (Dalby 2002, p. 132).

The increasing cultural contact with the Roman-Hellenistic world would suggest that the Meroitic elite were also adopting Roman cuisine. It is quite likely that pepper and spices were used in the preparation of luxury foods on festive occasions and became an important part of social display, as was their early use of imported wine seen through ceramic containers. Goods coming from India consisted of material that is difficult to detect archaeologically, such as spices and pepper, in addition to textiles. 
Large amounts of different types of food have been recovered that document contact with India, especially from Berenike (Sidebotham 2011, pp. 227-229). An indication of the importance of pepper is a find from Berenike where the largest cache of pepper from the Roman period has been recovered, namely, a storage jar containing $7.5 \mathrm{~kg}$ of black peppercorns (Sidebotham 2011, pp. 227, see also this issue). This object was recovered from the courtyard of the Serapis Temple dated to the first century CE (Sidebotham 2011, p. 227). It was exported in huge quantities from the southern coast of Malabar (Tomber 2008, p. 55; Thapar 2000, pp. 15-16). Pepper was of three types: white pepper, long pepper (the most expensive, exported from Barbaricon and Barygaza in the north), and black pepper exported from the Malabar Coast in the south. Dalby (2002, p. 132) discusses its importance and refers to Roman traders who came with gold and departed with pepper.

With these discoveries from Berenike, we have the first hard archaeological evidence of the dimensions and importance of the pepper trade between India and the Roman Empire as described in the written sources. Other important trade items mentioned by Periplus were cotton textiles and indigo dye (Casson 1989, pp. 194195). It is also possible that such culinary goods could have been imported along the Nile corridor alongside other luxury items. However, we should bear in mind that trade along the Red Sea corridor was significant to the Meroitic elite. Texts testify to the export of ivory from Adulis and its hinterland. African ivory was especially popular in the Indian subcontinent because of its higher quality than the Indian equivalent (Huntingford 1980, pp. 22-23).

It is likely that there was differentiation between the elite and the masses with regard to basic foodstuffs: the elite relying more on Meroitic cuisine based on bread, made from wheat and barley cultivated by irrigation on the banks of the Nile, while the ordinary people relied on African cuisine based on millet porridge. These differences in food with an emphasis on bread are reflected not so much in the vessels used, as what we can see in the ritual offering tables in Meroitic temples or elite funeral tombs, where bread appears to be the main item offered (Shinnie 1967, p. 113; Adams 1977, p. 377; Welsby 1996, p. 93). Quite often, wine also seems to be used for libation. Imported luxury objects used for social display were significant and included silver, bronze goblets and serving bowls, what Edwards characterizes as "table ware" (2004, p. 167), plus wine and oil containers (amphora and bottles) testifying to imports from Egypt. Some wine was produced in Nubia but not very successfully; according to Adams (1977, p. 360), the elite appear to have consumed imported Egyptian wine.

The manufacture of textiles in the Indian sub-continent was one of the foremost industries and lucrative activities in Indian Ocean trade, closely supervised and controlled by the state. Textiles were regarded as valuable enough to be stored in the national treasury and described in the same category as various kinds of precious stones and gems (Pliny, 12.14.28; Casson 1989 PME, p. 221; Thapar 2002, p. 418; Ray 2003, p. 227). The finest cotton textiles appear to have come from Madhura, South India and Barygaza, which were manufacturing centres and transhipment points for these products (as described above for pepper). Barygaza is mentioned more than any other single place in the Periplus (Tomber 2008, p. 125). The importance of textiles in Indian Ocean trade is also manifested in the finds of several hundred pieces recovered at Berenike, these being Z-spun, which is the usual twist for Indian cotton (Wild and Wild 2000, p. 
246). Sidebotham (2011, p. 244) refers to several fragments of resist-dyed cotton cloth of Indian origin from the late Roman levels at Berenike; these have parallels in some Ajanta Cave paintings (see also Behl 1998; Wild 2006).

Textile production, especially cotton, was also important within Meroitic culture, both as a medium of exchange and a status marker (Edwards 2004, p. 170). It is interesting to note that the Periplus mentions imports to Adulis consisting of Indian cloth and some muslin as well as coloured lac (quoted in Munro-Hay 1982, p. 406). Textiles produced and traded within the Indian Ocean network are expected to have been given an additional value (Ray 2003, p. 218). I will follow Mary Helms' perspective (1993, p. 9), who has argued that

...by obtaining goods from afar, persons of influence or elite are involved in symbolically charged acts of both acquisition and transformation by which resources originating from locales outside society are obtained and brought inside society where they may be materially altered and/or symbolically reinterpreted or transformed to meet particular political-ideological requirements.

The elite demand for luxury consumer items was a major factor in stimulating the import of goods that served to express their position in local as well as in international arenas. This supports Adams' (1981) and Edwards' (1999a) arguments that control over trade routes was an important part of the political economy of the Meroitic state, and they see its wealth and power as being founded on control over trade rather than on a rich agrarian base. The imported trade goods consisted of luxury goods; this type of trade formed an important part of a wider prestige-goods economy where exotic artefacts were controlled by the ruler and redistributed through various channels to the elite. However, there are reasons to expect that the elite were also interested in goods that neither could easily be carried over a distance nor could easily be produced by locally available craftsmen.

\section{The Political Economy of the Meroitic Civilization}

Archaeological material shows that ironworking was a large-scale activity at Meroe. This is visible in the oft-noted remains of large slagheaps just outside the ancient city. The smelting of iron occurred close to the palace, which suggests that ironworking was controlled by the state. Unpredictable raids from different groups, especially the nomads of the savannah, were a serious political threat and might have been a factor contributing to the location of these activities. Grzymski (2008) argues that the chain of jebels or mountains that enclosed greater Meroe were probably occupied by sentries guarding the area against nomadic militant groups.

An important element of the Meroitic political setting was war and conflict. The success of the Kushite army is demonstrated by the survival of its state for over a thousand years. Without an efficient military force, it is unlikely that this would have been achieved. My suggestion is that state survival was made possible not only because a large amount of iron was being produced and made into weapons, but most importantly because of the centralized control over iron production. Such control must have been an important factor in the formation of the Meroitic state.

A temple dedicated to the royal god of war, Apedemak (Fig. 2), was built on a slag mound at the outskirts of the city, dated to the third century CE. Apedemak was a god 


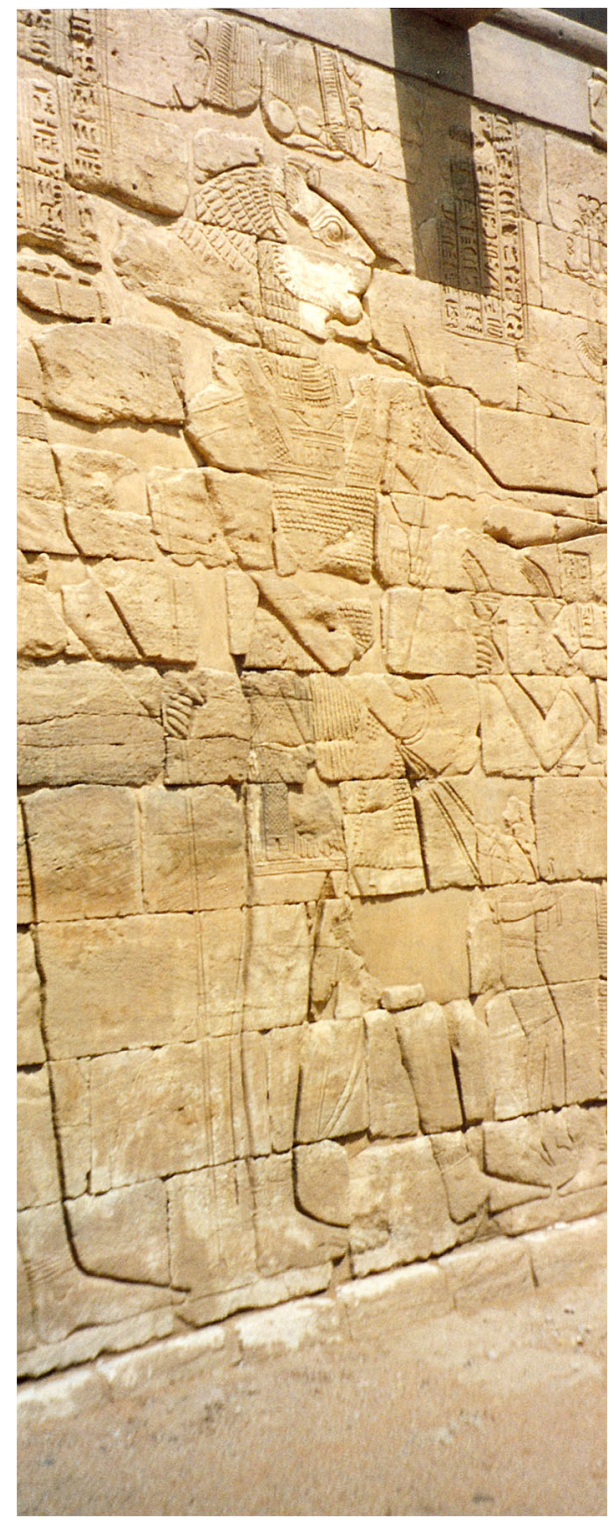

Fig. 2 The lion god Apedemak, the god of war holding a bow and arrow in one hand and a cord of prisoners in the other. A relief from the Apedemak temple at Musawwarat es Sufra (Photo by author)

of warfare, depicted with the means of destruction: bow and arrow, spears, swords. However, Apedemak symbolized two opposite but connected ideas - fertility and life as well as warfare and death (Zabkar 1975; Haaland and Haaland 2007). He is sometimes depicted with a bunch of sorghum being offered to the queen (Torok 1997). The Meroitic name Apedemak has been translated as "creator god," tracing apede back to the Nilo-Saharan root in the Proto-North-East-Sudanic sub-phylum (Rilly and de Voogt 2012, pp. 102-103). 
It is likely this temple was built to honour this god and can thus be perceived as important ideologically and ritually in legitimating the political power of the ruler. In the political control and monopoly of ironworking, the early savannah states like Meroe were significantly based on military technology, in which iron products played an essential role. The political control of iron products was thus very important. Iconography and burial finds also show the significance of iron objects related to the ruling elite (Haaland and Haaland 2007). The significance of the association of Apedemak with warfare and the bow and arrow to legitimating the political power of the ruler has a long history. Earlier Kushite kings had received the bow and arrow as royal insignia during the coronation at Kawa (Table 2).

Research during the last decade has revealed several royal sites in the Meroitic heartland between the fifth and sixth cataract areas along the Nile. At several of these sites, remains of extensive ironworking have been recovered, with workshops located close to temples. The most prominent are the sites of Muweis, el Hassa and Hamadab dating to the Classical Meroitic period (Muweis dates from the late first century BCE to the first century CE; Baud 2009). These sites were built during the height of Meroitic power and provide further support for the importance of temples in the centralized control of iron production. As argued in earlier articles, iron was also an important trade item exported to Egypt (Haaland and Haaland 2007; Haaland 2013)

The internal organization of the production and distribution of significant objects was critically linked to involvement in inter-state exchanges. In the international system of kingdoms and empires, interstate interactions were characterized by competition as well as shifting alliances involving both warfare and trade. Ruling elites would have had a keen interest in attracting skilled craftsmen of various kinds, not only for producing means of destruction and production, but also for the creation of symbolic forms that express power relations between states, as well as internal differentiation between the ruling elite and the ordinary members of the state. It is likely that there was international demand for skilled craftsmen, and also that political elites would have tried to attract such people from other kingdoms. Since early large-scale states seem to have been organized in guilds or along caste-like principles, such craftsmen could easily have fit into the social organization of different kingdoms. An example of this may be provided by the work on Meroitic iron production by Abdu and Gordon (2004). They analysed objects from the Early to the Classic period (300 BCE$250 \mathrm{CE}$ ) and suggest that these objects represent a distinctive iron-making style not found in the Eastern Mediterranean or in sub-Saharan Africa. Rather, they suggest the transmission of knowledge to Meroe from the east, perhaps from India. They emphasize the deliberate use of iron-arsenic alloys and piled metal, probably to achieve distinctly decorated surfaces. They argue that this material suggests that knowledge of making iron objects might have been introduced via trade across the Indian Ocean. This is important new information and needs to be investigated further. Data which seem to support this connection concern the import to Adulis of Indian iron, mentioned in the Periplus (quoted by MunroHay 1982, p. 406). Killick has also suggested that ironworking might have been introduced to Eastern Africa from the Indian subcontinent (Killick, personal communication, July 2013). The cultural influence related to iron production needs to be investigated further. 


\section{Symbolic Legitimation of Power}

Legitimating power is an important state concern, and states everywhere have a cultural policy of developing convincing and compelling symbols buttressing the brute force based on material control. An important aspect of legitimation in ancient civilizations is monumental expressions communicating the state's power in relation to competing states, as well as in relation to the masses it claims to protect within its boundaries. In the construction of monuments, rulers are stimulated to draw on symbolic features containing elements that seem convincing and compelling in the international arena, as well as in the local one. Furthermore, rituals, ceremonies and monumental symbolic structures are linked to religious beliefs underpinning the divine rights of the rulers.

The Kushite states were located on the fringes of the mighty Egyptian empire, where a rich inventory of symbolic constructions legitimated a state that maintained continuity over several thousand years. The strength of the early Kushite states was highly dependent on their relations to the Egyptian empire; so, it is understandable that the Kushite rulers at Napata largely used Egyptian symbols to legitimate their rule-symbols intimately associated with the divine role of the Egyptian Pharaoh.

However, during the time of the Meroitic kingdom the situation in the international arena changed dramatically. During the period of axial breakthroughs, traditional legitimating ideologies were challenged in all major empires of the ancient AfroAsian world. Egyptian political and ideological influence had been weakened by the Ptolemaic conquest and seaward trade over the Indian Ocean increased. These dramatic global changes in trade, power and ideology had, I suggest, a significant impact on the symbolic expression of legitimating ideology that took place in the late Meroitic kingdom. In this context, the focus here is on two enigmatic features: the lion god Apedemak and elephant representations.

\section{The Archaeological Evidence}

The region in which representations of Apedemak and elephants have been found is Butana, the heartland of the Meroitic Empire, which held a strategic position on the trade route between the Nile and the Red Sea. Specifically, they are mainly found in the ancient Meroitic cities of Naqa and Musawwarat es Sufra.

I start with Naqa, located $29 \mathrm{~km}$ east of the Nile. Naqa is famous for a number of temples and religious buildings. The so-called Roman Kiosk is a small temple or chapel situated in front of the Lion Temple dated to the first century CE. It reflects a crossroads of influences from Roman-Hellenistic culture as well as Egyptian and indigenous cultures. Inside the Lion Temple, one can see a Roman-inspired god depicted in fullface with Mediterranean-type beard, wearing the crown associated with the lion god Apedemak (Shinnie 1967, p. 92; Kroeper 2011; Wildung 2011). This shows how elements linked to different cultural traditions are blended together in various religious contexts. The conventional wisdom has been to see this as a Classical influence inspired from the Mediterranean north. Naqa comprises extensive remains of settlement structures, palaces, temples and cemeteries (Edwards 2004, p. 150); recent work suggests that the settlement of mud brick and redbrick buildings and even more palatial 
structures were more extensive than earlier alleged (Kroeper 2011; Wildung 2011). The largest temple is dedicated to the Egyptian god Amen. A stele was recovered with the remains of writing both in Egyptian hieroglyphs and in Meroitic cursive text. Of special interest for our discussion is the exceptionally well-preserved Lion Temple dedicated to Apedemak. A most interesting scene is on the outside of the back wall, where Apedemak is uniquely represented as a three-headed god with four arms, a common attribute of Indian gods (Fig. 3). The manner in which Apedemak is holding his hands and displaying his fingers appears similar to Indian iconography, with hand positions in the mudra convention prominent within Hindu as well as Buddhist traditions. Another representation of Apedemak is from the same temple where the god is seen as emerging from what Shinnie (1967, p. 113) and Wildung (2004) notice as a lotus flower (1) in the shape of the body of a snake, iconography that is also reminiscent of Hindu and Buddhist traditions (Fig. 4). In India, these types of representation are quite often depicted in connection with Ashoka's edifices and along trade routes from the third century BCE through the Maurian period, 325-184 BCE. These so-called Pillars of Ashoka are mainly erected along the Gangetic plain, with major sites at Vaishali, Sarnath and Nandangarh (Thapar 2002, p. 230).

In the front pylons at the entrance of the Apedemak Temple, one can see the queen and the king both with weapons in their hands, destroying their enemies (Fig. 5). The temple was built by Queen Netakamani and King Amanitare in the first century CE. This was at a time when Kushite culture and building activities reached their peak (Adams 1977, p. 312; Burstein 2009a, b p. 9). According to Shinnie, they present attitudes derived from Egyptian originals (1967, p. 89); interestingly, Shinnie mentions features of their dress that appear to be non-Egyptian, and he indicates that these might be related to local African traditions (Shinnie 1967, p. 89). Another point to consider is

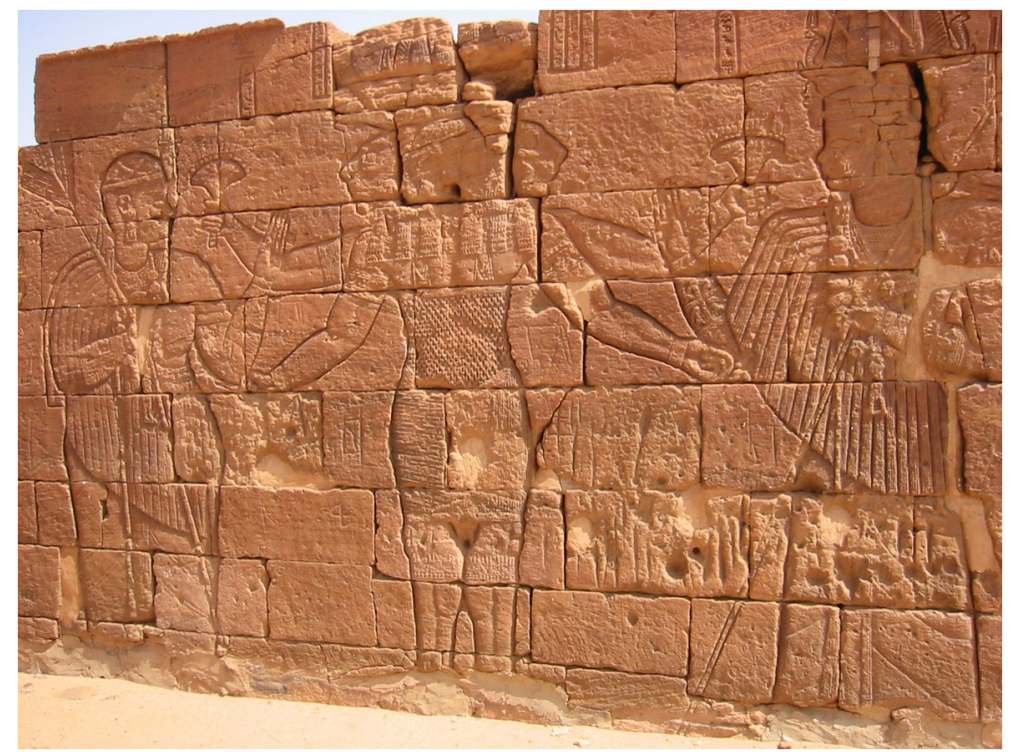

Fig. 3 A relief of Apedemak depicted as a three-headed god at the Lion Temple in Musawwarat es Sufra (Photo by author) 


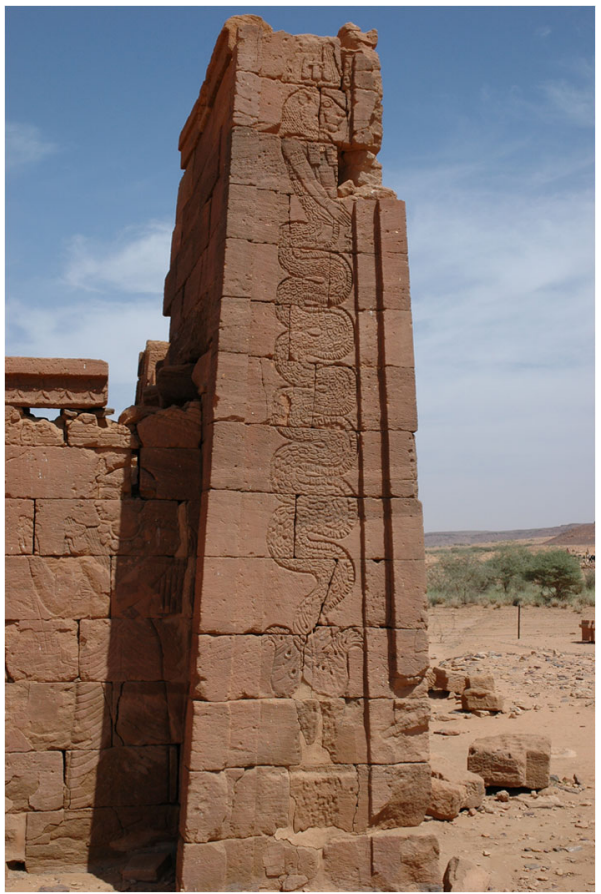

Fig. 4 Apedemak depicted as a lion-headed snake emerging from a Lotus. From the Lion Temple at Naqa (Photo: Ida Heierland)

the clothing, which might be linked stylistically to Indian traditions. We know textiles from India were an important trade item exported to the Red Sea as we have seen at

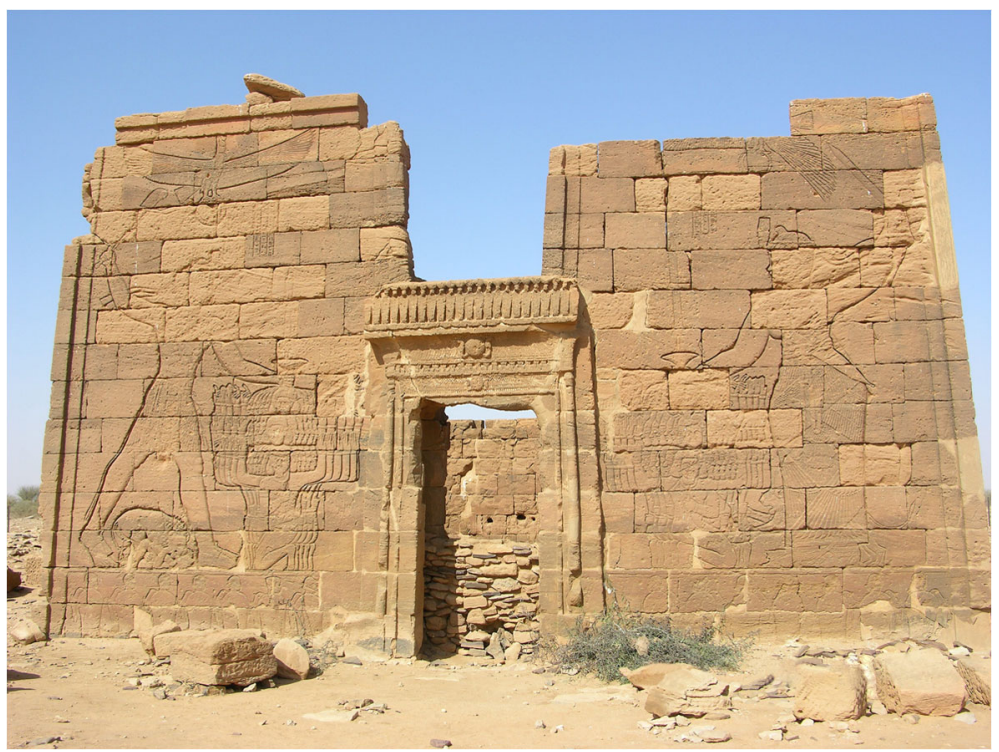

Fig. 5 Reliefs on the pylons of the Lion Temple, Naqa. The king Natakamani is to the left and the queen Amanitore is to the right. The queen holds a sword and the king, an axe (Photo: Mahmoud Beshir) 
Berenike. Thapar (1966, p. 116) also mentioned trade to Africa. We would thus expect textiles to be intended for use by the royal elite. As early as 1951, Arkell mentioned that textiles from India were important trade goods and referred especially to remains of textiles found at the western cemetery at Meroe (Arkell 1951, p. 32). This occurred at a time when the Meroitic Empire at the height of its political power and was involved in a global network of trade. Several literary sources refer to textiles being one of the most important and valuable trade items exported from India to Africa (Periplus, see Casson 1989; Thapar 1966, 2002; Ray 2003; Sidebotham 2011).

Another important site is Musawwarat es Sufra, which shows cultural influences from the Indian subcontinent and is located just $30 \mathrm{~km}$ east of the Nile north of Naqa. It is quite different from Naqa in that there are few settlements of a secular character, or cemeteries. Several archaeologists have regarded it as one of the most puzzling of the Kushite sites (Shinnie 1967; Welsby 1996; Wenig 2001; Edwards 2004). It is a very complex site with the remains of a variety of buildings and structures. It was seen by Wenig (2001) as a religious place and pilgrim centre. Edwards argues (2004) that the Meroitic royalty was closely linked to the site and played a central role during religious ceremonies. One of the most puzzling of the structures is the so-called Great Enclosure, covering $55,000 \mathrm{~m}^{2}$, one of the largest structures from the Meroitic period (Wenig 2001). It was occupied over a considerable period of time, from 270 BCE to CE 330, and consists of several temples, enclosures and corridors, as well as a garden and a pottery workshop where remains of more than 25,000 potsherds have been recovered. The large numbers of sherds of both fine Meroitic ware and coarser ceramics suggest that large-scale offerings of food/drinks took place there (Wolf 1997; Edwards 1999b; Wenig 2001).

We find here the most famous temple dedicated to the lion god Apedemak, the importance of whom is shown by numerous iconographic scenes. Indeed, the oldest representation of Apedemak is found here dated to the third century BCE (Torok 1997); one of the main scenes on the outer temple walls is of the king and the prince facing Apedemak, where he is being being worshiped by the royal family. The Apedemak temple thus clearly played an important ceremonial role for royalty.

In terms of the site of Naqa, it is discussed above that there were features that show that Apedemak was influenced by Indian culture. However, at the site of Musawwarat es Sufra, we do not find that Apedemak reflects Indian influence. Instead, there are several other cultural features indicative of Indian influences, such as a column drum showing a number of gods depicted in an unusual high relief, and one engraved figure in a yoga-like position. Shinnie noticed this unusual posture and workmanship and sees these engravings as being quite similar to Indian sculptures and reliefs (Shinnie 1967, P1. 22). Vercoutter suggested that Meroitic art was equally influenced by Indian and Egytian cultures (quoted in Shinnie 1967, p. 114).

What is most significant at this site is the number of representations of elephants, which suggests that this animal played an important role at Musawwarat. The ancient Meroitic name of the site itself, Aborepi, has been translated as "place of the elephant," tracing the word for elephant, abore, back to a Nilo-Saharan root in the Proto-Northeast Sudanic sub-phylum (Rilly and de Voogt 2012, p. 102). Shinnie sees the elephant as divine, similar to Apedemak (Shinnie 1967, p. 146), an interpretation that has created quite heated discussion (Hofmann 1975; Wenig 1978). Hofmann argued in 1975 that the elephant was not regarded as divine but was the carrier of the divine. One example 
that illustrates this is an engraving of an elephant carrying a divine king wearing the crown of Upper and Lower Egypt, with the royal religious insignia of a winged python on its back (Shinnie 1967, p. 95). According to Hofmann, these are features influenced by Indian symbolism, which he sees as evidence of substantial Indian influence (Fig. 6). However, this has been quite heavily criticized by Wenig (1978). As early as 1951, Arkell published an article on Meroe and India in which he argued that the elephant imagery might reflect the importance of Indian cultural influence on Meroe. He argues that the representation of the king riding bareback on an elephant, wearing the crown of Upper and Lower Egypt, is quite foreign to the Nile valley. A mahout, an elephant trainer, appears to be kneeling in front of the elephant. According to Arkell (1951), this scene is clearly inspired by Indian cultural traditions. It is suggestive of a ceremonial occasion as one finds in both Hindu and Buddhist traditions. Another relief on the northwest wall of the Lion Temple shows a file of elephants leading prisoners on ropes (Fig. 7). Similarly, this seems to refer to a ceremonial procession. Interestingly, the elephants are decked out in what appears to be an elaborately made cloth, which is quite unusual in Meroitic culture but common in India, as we can see of the relief of an elephant from the Pitalkhora cave, dated to the $c a$. second century BCE to second century CE (Fig. 8). This decoration of the cloth from Musawwarat seems quite distinct; a possible link to follow is to see if comparative material from South Asia can be found, such as the similarities discussed for the cotton textiles found at Berenike and Ajanta cave in India. Interestingly, we find inside the Apedemak temple several iconographic pictures of elephants that appear to have covers on their backs, although not as prominent as we see on the outside wall (Fig. 9).

The most enigmatic structure at Musawwarat is the so-called Great Enclosure, which has been the subject of various interpretations. It consists of a number of temples and

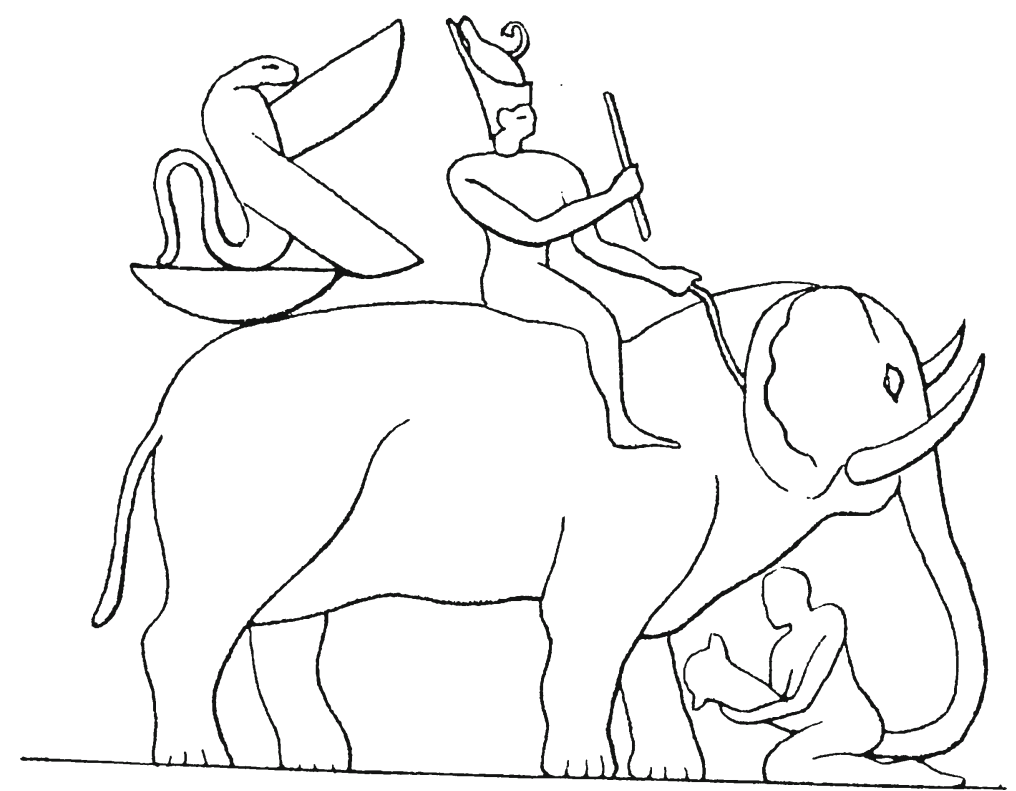

Fig. 6 A Meroitic king riding an elephant bareback, scene from a column drum in a temple at Musawwarat es Sufra. (From Lepsius 1849 Denkmaler V, Blatt 59-60) 


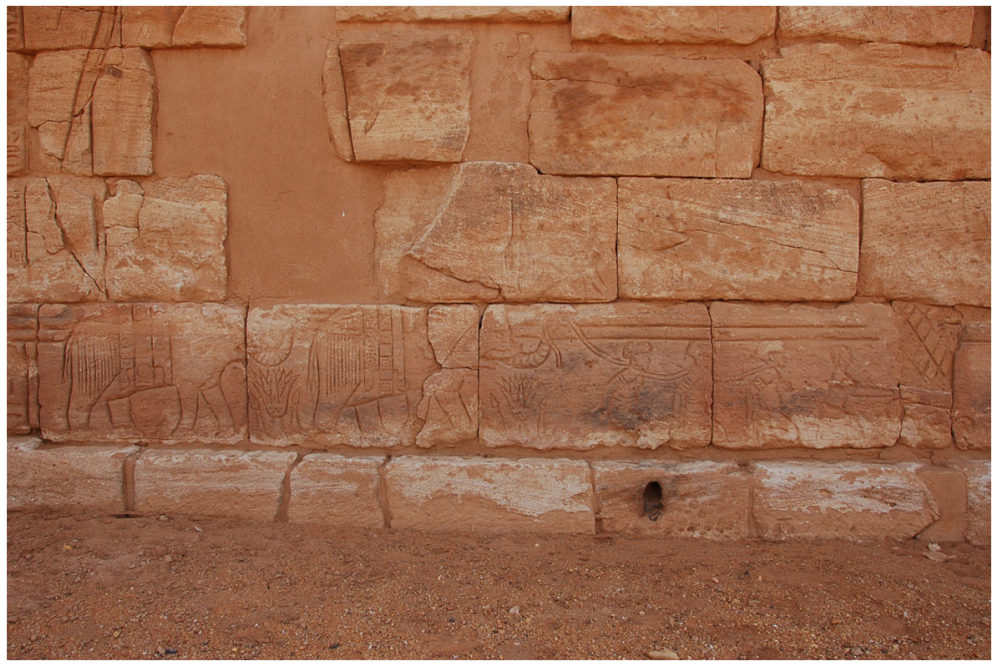

Fig. 7 Iconography of a procession of elephants with prisoners on a rope; note what looks like an elaborated cloth covering the back of the elephants. Apedemak temple, Musawwarat es Sufra (Photo: Maurice Mugabowagahunde)

long corridors connecting groups of buildings. These buildings are surrounded by numerous rooms that possibly served as storerooms, kitchens and workshops, probably to be used by priests as well as the royal family when attending important ceremonies (Wenig 2001). As early as 1967, Shinnie proposed the possibility that this structure was used for the taming and training of elephants (Fig. 10). A graffito on the temple wall of an elephant, which seems to be ascending a ramp, supports the interpretation that the temple might have played a role in the training of elephants (Welsby 1996, pp. 147). Wenig interprets the Great Enclosure as important in serving both cultic and profane purposes and could also have been a place for training elephants, which were sought

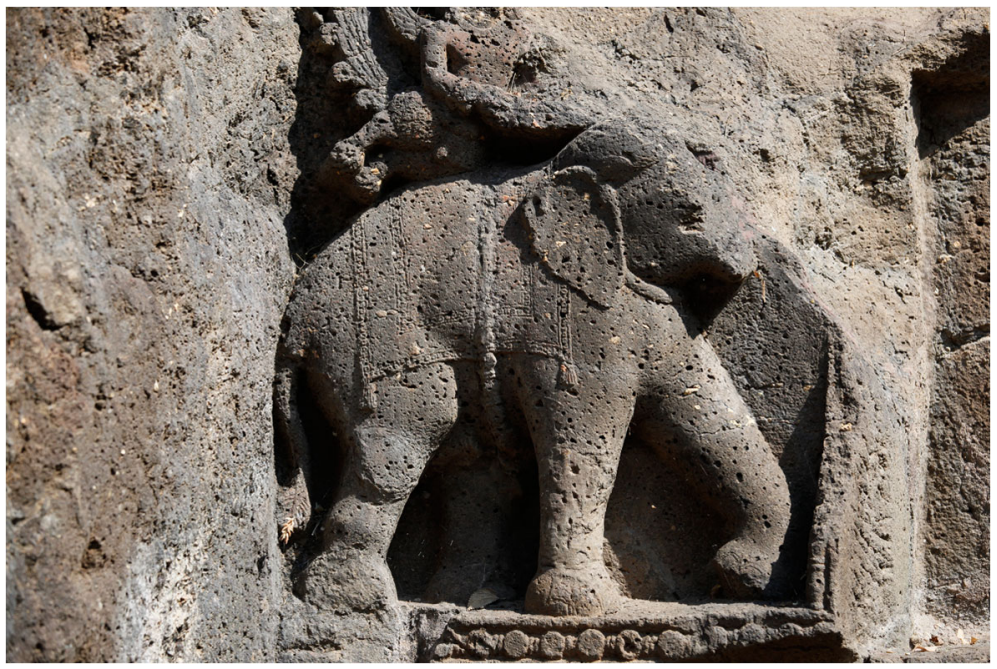

Fig. 8 Elephant relief from Pitalkhora cave, Maharashtsra, India (Photo: Torbjorn Haaland) 


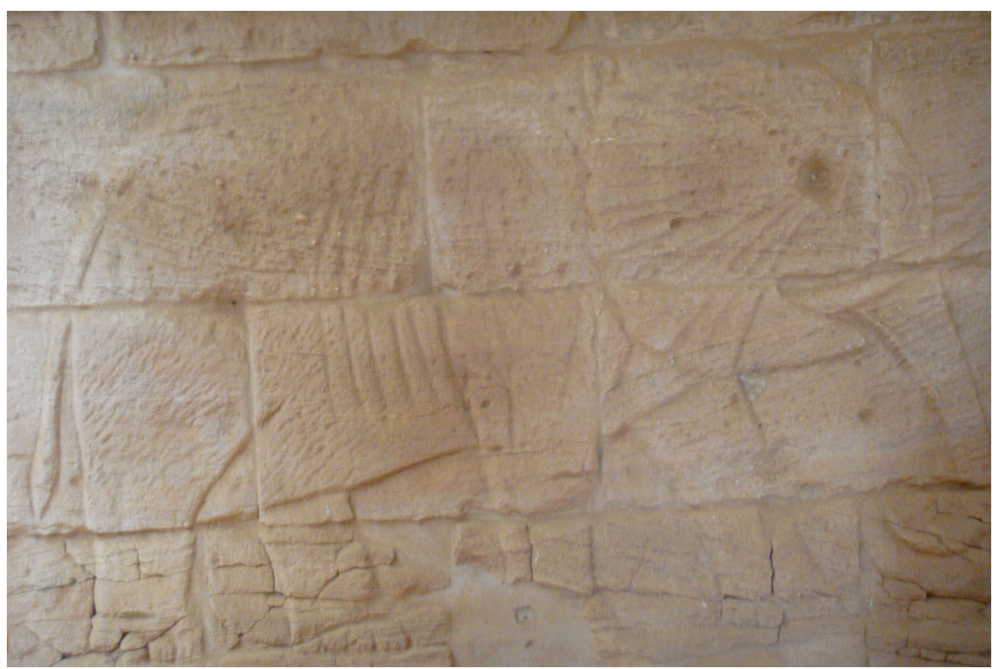

Fig. 9 Elephant depicted on a column inside the Apedemak Temple at Musawwarat es Sufra (Photo by author)

after in the Mediterranean world. He sees Musawwarat as a place where traders from the Mediterranean could have met their Kushite partners to obtain African elephants (Wenig 2001, p. 86). We know from written sources that the Ptolemies sent hunting expeditions south along the Red Sea to capture elephants (Adams 1977, p. 335; Welsby 1996, pp. 175-176; Phillips 1997; Phillipson 1998; Burstein 2008). Ptolemies saw the military importance of these animals and looked to sub-Saharan Africa to obtain a supply of them. The special structures found at Musawwarat might thus have been such a centre for training captured elephants.

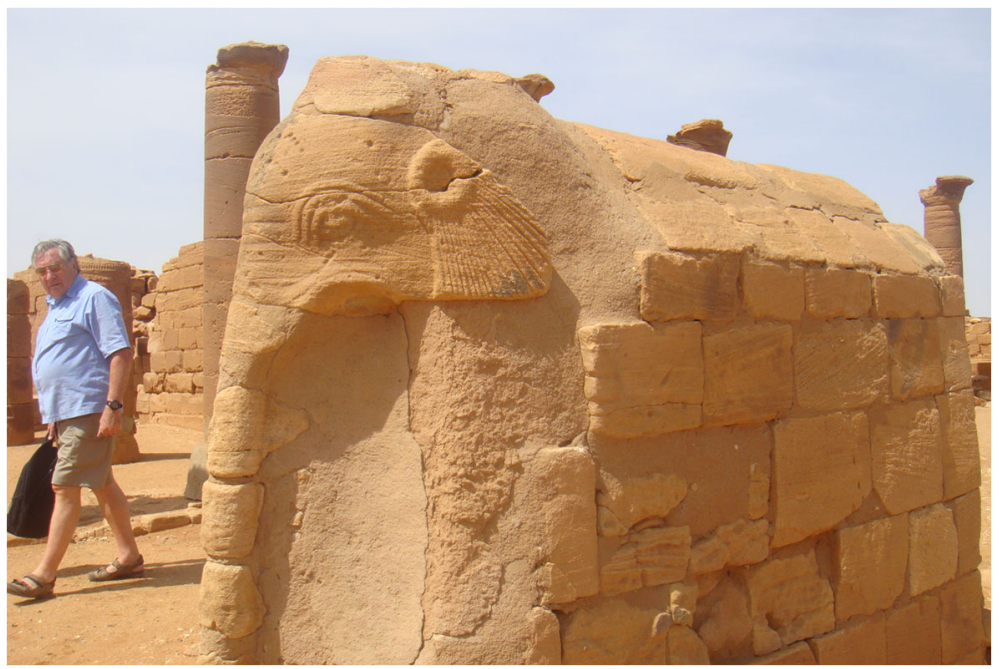

Fig. 10 Elephant from the central temple, inside the great enclosure at Musawwarat es Sufra (Photo by author) 
The importance of the elephants might have been in their use for warfare during the second to third century BCE. However, over time they seem to have been used more for display and ceremonial processions (Sidebotham 2011, p. 54). In the training of elephants, the Ptolemies and Kushites were dependent on Indian trainers, so-called mahouts. Kistler discusses the importance of the mahouts for training (Kistler 2007, p. 101); according to him, they dressed in clothing suggesting South Asian origins and even had Indian names despite being native to Africa. Sidebotham describes different ways by which the Indian elephants could be captured and domesticated by using enclosures or pits and suggests that the same methods could have been used in Africa (Sidebotham 2011, p. 45).

Anuraag Sanchi has argued that in India, elephants were managed by skills garnered and conveyed for generations within a small specialized community. The English word elephant is derived from the Sanskrit word for ivory (ibha+danta=elephant + teeth).

Unlike horses, elephants can be "ridden" only by specific individuals. Each elephant has a specific "rider(s)" - and mahavats or mahouts. Elephants trust individual riders and trainers, and this relationship is nurtured for the lifetime of an elephant.

The Kushite empire had along history of exchange of experts to other regions and cultures. The Assyrian king Sargon II (721-705 BCE) imported horse-training experts and horses from Kushite Nubia (Dalley 1985; Heidorn 1997). Not only was there an exchange of experts for training horses, but also the horses themselves which were quite sought after for the royal army of Sargon. Kushite kings (Taharqa, Piankhy) were also visiting the court of the Assyrian kings. The connections between Assyria and Nubia are seen in the artistic influence within both polities. Interestingly, it is especially in ivory art that two-way cultural influences can be detected. At the Nimrud palace, there are certain cultural elements seen in ivory inlay which are similar to stylistic features found on objects at the tomb of Taharqa. Likewise, objects found in royal graves in Nubia show relief styles, carved in a technique traditionally associated with Assyrians although the styles were used to portray purely Egyptian motives. This may indicate foreign craftsmen present at the Nubian court rather than indigenous workshops. Nubians were also familiar to Assyrian artists who depicted them on art objects and wall reliefs (Dalley 1985). Travellers did not only bring with them their expertise but also disseminated aspects of their cultures (Dalley 1985). Other researchers such as Heidorn (1997) have drawn attention to Kushites working in other jobs such as musicians, temple personnel, smiths and stone workers. This is recorded from Sargon II in $721 \mathrm{BCE}$ to the fall of Niniveh in $612 \mathrm{BCE}$. The horse training occupational specialists, whose skills were in demand in distant regions such as Assyria, were responsible not only for transmitting their skills but also for a flow of other experts and cultural ideas. I discuss below how the skills related to elephant trainers were transmitted over vast regions from India to Egypt and Meroe. With the flow of these experts, other occupational experts and stylistic ideas were disseminated.

It is not unlikely that ideas related to the symbolic world of India were transmitted to rituals in Meroe by experts, and that the mahouts were the carriers of these ideas. Here, we are faced with a puzzle since a closer look at the depicted elephants shows some similarities to Asian elephants, such as the shape and size of their ears. Were the African elephants depicted in a style that would have been familiar to the mahouts? If 
this scenario is possible, we could see the mahouts as specialist workers who may have moved over long distances between culturally distinct communities, leading to the diffusion of ideas associated with the animals. The mahouts may also have introduced ideas relating to a wider symbolic universe in the Indian subcontinent. The representations of elephants indicate that these animals played an important ceremonial role at the site of Musawwarat which points to Indian influences. We know that in India, the use of elephants in ritual processions was an essential cultural practice. This supports the idea that Musawwarat was an important ritual centre where the Great Enclosure was also used to house elephants required for religious ceremonies (Wenig 2001). It is interesting to note that the Meroites and the Indians were known as "Aithiopians" and both were associated internationally with elephant training.

\section{Conclusion}

Religion is a major factor in the moulding of social attitudes towards trade and seafaring activity, articulating norms and ethics. Religious functionaries travelled along trade routes forming close links with trading groups, and through these networks, religions such as Buddhism, Hinduism and Christianity spread around the Indian Ocean (Seland 2012, 2013). According to Ray (2003, p. 258), participants in maritime activities were followers of Buddhism as well as Hinduism and Jainism. However, Buddhism adopted an approach unlike its contemporaries, with an emphasis on rituals oriented towards protection against the perils and dangers encountered at sea. With their engagement in Indian Ocean trade, it is reasonable to expect that Indian traders were found in ports along the shores of the Red and Arabian Seas (Sidebotham 2011, p. 75).

Traders, sailors and artisan guilds were, to a large extent, dedicated adherents of Buddhism and significant donors to religion and sacred centres (Thapar 2000, p. 455). The exchange of envoys and gifts between the Indian Maurian Empire and the Ptolemaic rulers in Egypt served as forerunners for trade (Thapar 2000, p. 456). Buddhism was expanding at this time, and missionaries were sent to try to convert people to this religion.

The above background raises important questions concerning the relationship between the ruling decision-makers who commissioned the creation of important sites of royal symbolism like Apedemak and elephant-linked representations. Why did they choose elements with Indian-like attributes? Who were the specialists with knowledge and skills to create symbolic constructions that blended iconographic elements from different civilizations? Concerning the decision-makers, I find it plausible that it was the rulers of the Meroitic state who played a major role in promoting the creation of Apedemak and elephant representations, and that it is unlikely that a strong priesthood inspired by Egyptian religion played a major role. What I suggest is that it was Indian craftsmen who, in a bricoleur-like way, fashioned symbolic imagery with features linked to Indian as well as to Egyptian civilization. Such bricolage had the potential to represent the Meroitic state as a political unit on the same level as Egypt, at the same time that it contained features expressing that it was a distinct kingdom. Of course, such bricolage was oriented towards the cultural policy of the Meroitic rulers. The critical 
question is how craftsmen skilled in the construction of features representative of Indian traditions and symbolism were brought to the Meroitic state.

I think that the answer to this question has to be seen in the context of Indian trade; this trade not only involved the exchange of things, but may also have involved the import of Indian mahouts for preparing elephants for war and ceremonial processions, and it might also have involved the migration of other skilled craftsmen between states based on similar caste-like divisions of labour (Haaland and Haaland 2007). During the time of the Kushan Empire in northwest India, there was a boom in Buddhist-inspired art and architecture connected with guild/caste specialization and monasteries (Ray 2003). This art was a kind of hybrid Indian-Greek style of the so-called Gandhahara tradition and was influenced by the Graeco-Roman style of Alexandria (Thapar 1966, p. 119). Craftsmen from Kushan would thus have been familiar with the creation of hybrid expressions like those we see in Apedemak iconography. The migration of craftsmen between regionally separated states was thus an important mechanism in the diffusion of cultural elements across civilizations.

As Ray (2008, p. 216) has argued, this flow of people and ideas was facilitated by occupational specialists who moved between societies organized on similar caste-like principles: in India legitimated by Hindu beliefs and in Africa legitimated by beliefs drawn from other cultural traditions, as demonstrated in our analysis of caste in Ethiopia (Haaland et al. 2004). Such movements linked artisans in a variety of networks within local communities as well as within pan-regional groupings. Ray sees them as interacting with institutions of the state and with religious centres on different levels (2003, p. 223).

Several finds recovered at sites along the Red Sea coast, such as different types of ceramics, indicate that predominantly Indians used these items. The distribution of such pottery also indicates that foreigners lived or worked in separate quarters (Tomber 2008, pp. 75, 138).

The movements of mobile craftsmen seem to have played a major role in the diffusion of ideas in ancient civilizations, as we discussed above in connection with trading of horses and movement of horse trainers during earlier Kushite history. This is also exemplified by Taylor (1992) in his analysis of the famous Gundstrup silver cauldron found in Denmark. He argues convincingly that there are significant similarities between the deities depicted on the cauldron and the depiction of deities found on the Indian subcontinent. Furthermore, he suggests that figures on the cauldron are depicted in a posture similar to Hindu gods. The symbolism of the finely crafted cauldron, in his opinion, connects Europe with South Asia, which may have occurred by the migration of itinerant craftsmen serving priesthoods or political rulers. Taylor thus sees the craftsmen who made the cauldron as part of interlinked networks, which played an important role in cultural transmission (Taylor 1992, p. 719).

In a similar way, Helms (1993) and Killick (2009) have discussed the way artisans may have moved over long distances between culturally different communities, leading to the diffusion of their artefacts as well as cultural ideas associated with such objects. Mary Helms apply the concept of skilled crafting not only to the production of material things but also to a number of other activities that produce comparable elite-based forms of meaning including song, dance and music (Helms 1993, p. 14). It is within this framework that I see the mahouts as skilled artisans. It is here hypothesized that 
such diffusion may be manifested in the iconography of the lion god Apedemak and of representations of elephants.

Acknowledgments This article is based on ideas presented at the World of Iron conference in London 2009 and the Nubian conference at the British Museum in August 2010. I benefited greatly from the discussions generated by these presentations. Special thanks go to Abdul G. Mohammed and Roger Blench, who brought to my attention the special features of the elephants at Musawwarat es Sufra and their suggestion that I should look for South Asian connections. I also want to thank Mahmoud Beshir, as well as Maurice Mugabowagahunde, for accompanying me to Musawwarat and for interesting discussions at the site. Many thanks to Julie Anderson in helping to get hold of important literature. Most of all, I want to thank Jeremy Pope for his ideas that he freely shared with me and his important comments, which encouraged me to look closer at material from Assyria. As always, I thank Gunnar Haaland for important comments.

Open Access This article is distributed under the terms of the Creative Commons Attribution License which permits any use, distribution, and reproduction in any medium, provided the original author(s) and the source are credited.

\section{References}

Abdu, B., \& Gordon, R. (2004). Iron artefacts from the land of Kush. Journal of Archaeological Science, 31, 979-998.

Adams, W. W. Y. (1977). Nubia: Corridor to Africa. Princeton: Princeton University Press.

Adams, W. W. Y. (1981). Ecology and economy in the Empire of Kush. Zeitschrift fur Agiptische Sprache und Alterumskunde, 108, 1-11.

Anderson, J. R., \& Ahmed, S. (2009). What are these doing above the Fifth Cataract!! Napatan royal statues at Dangeil. Sudan \& Nubia, 13, 78-86.

Arkell, A. J. (1951). Meroe and India. In W. F. Grimes (Ed.), Aspects of archaeology in Britain and beyond (pp. 32-38). London: H. W. Edwards.

Arkell, A. J. (1961). History of Sudan: From the earliest times to 1821. London: Athole Press.

Arkell, A. J. (1966). The Iron Age in the Sudan. Current Anthropology, 7, 451-452.

Barnard, H., \& Magid, M. A. (2004). Eastern Desert Ware from Tabot (Sudan). Archéologie du Nil Moyen, 10, 15-34.

Baud, M. (2009). The Meroitic royal city of Muweis: First steps into an urban settlement of riverine Upper Nubia. Sudan \& Nubia, 12, 52-63.

Behl, B. K. (1998). The Ajanta cave. Artistic wonder of ancient Buddhist India. New York: Harry N. Abrams.

Bonnet, C. (2004). Kerma. In D. Welshby and J. A. Anderson (Eds.), Sudan. Ancient Treasures (pp. 70-79). London: The British Museum Press.

Burstein, S. M. (2008). Elephants for Ptolemy II: Ptolemaic policy in Nubia in the third century BC. In P. McKechne \& P. Guillaume (Eds.), Ptolemy II Philadelphus and his world (pp. 135-146). Leiden: Brill.

Burstein, S. M. (2009a). Ancient African civilizations. Kush and Axum. Princeton: Markus Wiener Publishers.

Burstein, S. M. (2009b). Another Nubian prince in Constantinople, new light on the last days of Kush. Beitrage zur Sudanforshung, 10(10), 5-8.

Campell, J. (1979). The masks of god. Oriental mythology. New York: Viking Press.

Casson, L. (1989). The Periplus Maris Erythraei: Text with introduction. translation and commentary. Princeton: Princeton University Press.

Dalby, A. (2002). Dangerous tastes: The story of spices. Berkley: University of California Press.

Dalley, S. (1985). Foreign chariotry and cavalry in the army of Tiglast-Pileser III and Sargon II. Iraq, 47, 31-48.

Edens, C. M., \& Kohl, P. M. (1993). Trade and world systems in Early Bronze Age Western Asia. In D. Begley \& R. D. De Puma (Eds.), Trade and exchange in prehistoric Europe (pp. 17-34). Oxford: Oxbow Monographs 33.

Edwards, D. N. (1999a). Meroe in the Savannah-Meroe as a Sudanic kingdom? Meroitica, 15, 312-320.

Edwards, D. N. (1999b). A Meroitic pottery workshop at Musawwarat es Sufra. Meroitica, 17(2).

Edwards, D. N. (2004). The Nubian past. An archaeology of the Sudan. London: Routledge.

Eisenstadt, S. (2009). Axial visions and axial civilizations: The transformations of world history between evolutionary tendencies and institutional formations. In P. Hedstrom \& B. Wittrock (Eds.), Frontiers of sociology (pp. 113-146). Leiden: Brill. 
Grzymski, K. (2008). Recent research at the palaces and temples of Meroe. In W. Godlewski \& A. Latjar (Eds.), Between the Cataracts: Proceedings of the 11th Conference for Nubian Studies (pp. 227-238). Warsaw University: Polish Centre of Mediterranean Archaeology.

Haaland, R. (1992). Fish, pots and grain: Early and Mid-Holocene adaptations in the Central Sudan. African Archaeological Review, 10, 43-64.

Haaland, R. (2013). Iron working in an Indian Ocean context. In J. Humphris and T. Rehren (Eds.), World of Iron (pp. 146-155). London: Archetype.

Haaland, G., \& Haaland, R. (2007). God of war, worldly ruler, and craft specialists in the Meroitic Kingdom of Sudan. Journal of Social Archaeology, 7, 372-392.

Haaland, G., Haaland, R., \& Dea, D. (2004). Furnace and pot; Why is the iron smelter a big pot maker? Azania, 39, 146-165.

Heidorn, L. A. (1997). The horses of Kush. Journal of Near Eastern Studies, 56, 105-114.

Helms, M. (1993). Craft and kingly ideal. Art, trade and power. Austin: University of Texas Press.

Hofmann, I. (1975). Wege und möglichkeiten eines indischen einflusses auf die Meroitische kultur. Bonn: Verlag Des Anthropos-Institus St. Augustin.

Huntingford, W. G. B. (1980). The Periplus of the Erythraean Sea. London: Hakluyt Society.

Jaspers, I. (1957). Vom urspunge und ziel der Geschichte. Fischer Burcherei KG: Frankfurt am Main.

Killick, D. (2009). Agency, dependency, and long-distance trade. In S. Falconer and C. Redman (Eds.), Polities and power: Archaeological perspectives on the landscape of early states (pp. 179-207). Tucson: University of Arizona Press.

Kirwan, L. P. (1972). The Christian topography and the Kingdom of Axum. Geographical Journal, 138, 167-177.

Kistler, J. M. (2007). War elephants. Lincoln and London: University of Nebraska Press.

Kroeper, K. (2011). Die stadt in der steppe-grabungen des Agyptischen Museums Berlin in Naqa, Sudan. Berlin: Staatliche Museen Preußischer Kulturbesitz.

Lepsius, K. R. (1849). Denkmaler as Aegypten und Aethiopien. (Plates). Band 5. Berlin.

Magid, A. M. (1998). Ancient waystations in the southern Red Sea Hills: A new discovery. Sudan Notes \& Records, 2, 1-12.

Manzo, A. (2004). Late Antiquity in Eastern Sudan. Sudan \& Nubia, 8, 75-83.

Munro-Hay, S. (1982). The foreign trade of the Axumite port of Adulis. Azania, 17, 107-126.

Peake, L. (2010). Egypt at the height of its power and a historiographic analysis of the regimes legacy. The invisible superpower: Review of the geopolitical status of Kushite ( $25^{\text {th }}$ dynasty). In W. Godlewski, \& A. Latjar (Eds.), Between the Cataracts: Proceedings of the 11th Conference for Nubian Studies (pp. 465476). Warsaw: Warsaw University.

Phillips, J. (1997). Punt and Axum; Egypt and the Horn of Africa. Journal of African History, 38, 423-457.

Phillipson, D. W. (1998). Ancient Ethiopia. Axum: Its antecedents and successors. London: British Museum Press.

Polanyi, K. (1957). The economy as instituted process. In K. Polanyi, C. Arensberg, \& H. Pearson (Eds.), Trade and markets in early empires. New York: Free Press.

Pope, J. (2008). The Demotic Proskynema of a Meroitic envoy to Roman Egypt (Philae 416). Enchoria, 31, 68-103.

Ray, P. H. (2003). The archaeology of seafaring in ancient South Asia. Cambridge: Cambridge University Press.

Rilly, C. (2004). The linguistic position of Meroitic. ARKAMANI: Sudan Electronic Journal of Archaeology and Anthropology. http://www.arkamani.org/arkamani-library/meroitic/rilly.htm. Accessed 1 March 2004.

Rilly, C. (2007). La langue du royaum Meroe. Un panorama de la plus ancienne culture écrite d'Afrique subsaharanne. Paris: Honore Champion.

Rilly, C. (2009). Le Méroitique et sa famillie linguistique. Louvain: Peeters.

Rilly, C., \& de Voogt, A. (2012). The Meroitic language and writing system. Cambridge: Cambridge University Press.

Sadr, K. (1990). The Medjay in the Southern Atbai. Archéologie du Nil Moyen, 4, 63-87.

Seland, E. H. (2012). Trade and Christianity in the Indian Ocean during Late Antiquity. Journal of Late Antiquity, 5, 72-86.

Seland, E. H. (2013). Network and social cohesion in ancient Indian Ocean trade: Geography, ethnicity, religion. Journal of Global History, 8, 373-390.

Shinnie, P. L. (1967). Meroe: A civilization of the Sudan. London: Thames and Hudson.

Sidebotham, S. (2011). Berenike and the ancient maritime spice route. Berkley: University of California Press.

Taylor, T. (1992). The Gundestrup cauldron. Scientific American, 266, 84-89.

Thapar, R. (1966). A history of India. London: Penguin Books.

Thapar, R. (2000). Cultural pasts. Essays in Indian history. New Dehli: Oxford Indian Paperback. 
Thapar, R. (2002). Asoka and the decline of Mauryas. New Dehli: Oxford University Press.

Tomber, R. (2008). Indo-Roman trade. From pots to pepper. London: Duckhworth.

Torok, L. (1989). Kush and the external world. Meroitica, 10, 49-215.

Torok, L. (1997). The Kingdom of Kush. Handbook of the Napatan-Meroitic civilization. Leiden: Brill Academic Publishers.

Trigger, B. G. (1969). The myth of Meroe and the African Iron Age. African Historical Studies, 11(1), $23-50$.

Trigger, B. G. (1985). Land and trade as patterns in Sudanese history. In M. Liverani, A. Palmieri, \& R. Peroni (Eds.), Studio Di Paletnologia in Onore di Salvatore M. Puglisi (pp. 465-475). Rome: Università di Roma.

Welsby, D. (1996). The Kingdom of Kush. London: The British Museum Press.

Wenig, S. (1978). Review. Inge Hofmann: Wege und möglichkeiten eines indischen einflusses auf die Meroitische kultur. Journal of Egyptian Archaeology, 64, 177-178.

Wenig, S. (2001). Musawwarat es Sufra, Interpreting the Great Enclosure. Sudan \& Nubia, 5, 71-88.

Whitewright, J. (2007). How fast is fast? Technology, trade and speed under sail in the Roman Red Sea. In J. C. M. Starkey, P. Starkey, \& T. Wilkinson (Eds.), Natural resources and cultural connections of the Red Sea (pp. 77-87). Oxford: BAR International Series 1661.

Wild, J. P. (2006). Berenike: Archaeological textiles in context. In Textiles in situ: Their find spots in Egypt and neighbouring countries in the first millennium CE, 175- 255. Bern: Switzerland.

Wild, J. P., \& Wild, F. C. (2000). Textiles. In S. Sidebotham \& W. Z. Wendrich (Eds.), Report of the 1998 excavations at Berenike and the survey of the Egyptian Eastern Desert, including excavations in Wadi Kalalat (pp. 251-274). Leiden: Centre for Non-Western Study.

Wildung, D. (2004). Kushite religion: Aspects of the Berlin excavation at Naqa. In D. Welsby \& J. Anderson (Eds.), Sudan's ancient treasures (pp. 174-185). London: British Museum.

Wildung, D. (2011). Die Stadt in der Steppe Grabungen des Agyptischen Museums Berlin im Sudan. Berlin. Wolf, P. (1997). Recent fieldwork at Musawwarat es Sufra. Sudan \& Nubia, 1, 20-29.

Zabkar, L. V. (1975). Apedemak, lion god of Meroe. Warmeister: Ariel and Phillips. 